\title{
Mobile Learning of Education Character based on Multicultural Value
}

\author{
Yoyo Zakaria Ansori ${ }^{1}$, Erik Santoso ${ }^{2 *}$ \\ DOI: $10.35445 /$ alishlah.v13i2.613
}

\section{Info Artikel}

Keywords:

Character building

Multicultural Education

M-Learning Attitude of

Tolerance

Kata kunci:

Pendidikan Karakter

Pendidikan

Multikultural

M-Learning

Sikap Toleransi

\section{Abstract}

This study aims to provide an understanding of character education based on multicultural values in elementary school students. The method used is quasiexperimental to see the changes that occur after using mobile learning in class VI SDN Kadipaten 1 Majalengka. The population and sample of the study were the sixth-grade students of SDN Kadipaten Majalengka in the 2020/2021 academic year. The data collection technique used a test that was used to determine the student's tolerance attitude. Based on the data processing and analysis results, it can be concluded that the attitude of tolerance needs to be given a good understanding at the level of elementary school students. It is because elementary school students are at a stage where imitation is very high. The "Smart-Ku" M-Learning application can be a facility in providing an understanding of tolerance. It is shown that the results of the study indicate that there are differences in tolerance attitudes before and after using the "Smart$\mathrm{Ku}$ " M-Learning application

\begin{abstract}
Abstrak
Penelitian ini bertujuan untuk memberikan pemahaman mengenai pendidikan karakter berbasis nilai multikultural di siswa sekolah Dasar. Metode yang digunakan adalah quasi eksperimen untuk melihat perubahan yang terjadi setelah digunakan mobile learning pada siswa kelas VI SDN Kadipaten 1 Majalengka. Populasi dan Sampel penelitian yaitu siswa kelas VI SDN Kadipaten Majalengka tahun pelajaran 2020/2021. Teknik pengumpulan data menggunakan tes yang digunakan untuk mengetahui sikap toleransi siswa. Berdasarkan hasil pengolahan dan analisis data didapatkan kesimpulan bahwa sikap toleransi perlu diberikan pemahaman yang baik pada tingkatan siswa sekolah dasar. Hal ini dikarenakan Siswa sekolah dasar merupakan tahap dimana sifat meniru sangat tinggi. Aplikasi M-Learning "Smart-Ku" dapat menjadi fasilitas dalam memberikan pemahaman mengenai sikap toleransi. Hal ini diperlihatkan bahwa hasil penelitian menunjukan bahwa terjadi perbedaan sikap toleransi sebelum dan sesudah menggunakan aplikasi M-Learning "Smart-Ku".
\end{abstract}

\footnotetext{
${ }^{1}$ Universitas Majalengka, Majalengka, Indonesia

Email: al.anshoryo928@unma.ac.id

*2 Universitas Majalengka, Majalengka, Indonesia

Email: eriksantoso@unma.ac.id
} 


\section{INTRODUCTION}

The results of ethnological research identify that approximately 600 ethnic groups have their respective group identities and have different cultures from one group to another. Meanwhile, the census of educators recorded more than 200 ethnic groups in Indonesia with a total population of 237 million as citizens(Alwasilah, 2012; Yoyo Zakaria Ansori et al., 2019a, 2019b). This very diverse culture makes the country of Indonesia has its pride. It is because the cultural diversity in other countries is not as much as in Indonesia. Therefore, developing a multicultural education direction is necessary as an ingredient of a sustainable development process. Multicultural education is the actualization of the educational process that prioritizes cultural and ethnic diversity in a country (Standley, 2000; Verma et al., 2020; Voronchenko et al., 2015).

The condition of diversity owned by the Indonesian nation, apart from being a good capital in developing its artistic potential, but on the other hand, such conditions allow for clashes between cultures, races, ethnicities, religions, and values prevailing in society. Several cases that led to conflicts with Sara's background occurred in Indonesia, undermining the Unitary State of the Republic of Indonesia (NKRI) if left unchecked. The disputes that happened, for example, were the cases of Ambon, Sampit, Poso, Aceh, and so on. while the research results by the Center for the Study of Islam and Society (PPIM) UIN Syarif Hidayatullah, for example, showed that $43.88 \%$ of the 1,859 students who were respondents in this study tended to support intolerant actions and $6.56 \%$ supported religious radicalism. (PPIM-UIN, 2017). Not only doing acts of intolerance based on an attitude of rejecting differences, in everyday life at school, some students admit that they are also accustomed to doing acts of bullying or persecution. As many as $36.2 \%$ of respondents admitted that they had carried out acts of bullying even though the intensity was rare.

Meanwhile, as many as $5.8 \%$ of respondents admitted that they often carried out acts of persecution against other friends. Most of the forms of persecution that students do to their friends (33\%) are in the form of verbal abuse, namely harsh words, such as cursing, rebuking, and the like that are hurtful. Meanwhile, other forms of persecution were bullying (14.4\%), spreading untrue rumours (11.4\%), or taking physical actions to friends, such as hitting, kicking, and the like (6.4\%). If this condition is left unchecked, it will threaten the integrity of the state, especially in terms of tolerance (Tilaar, 2004). Therefore, a culture of tolerance must be cultivated in students in elementary schools (Itzchakov \& Reis, 2020; Ma`arif, 2019; Roslinda, 2020; Shaposhnikova et al., 2013; Vangrunderbeek \& Tolleneer, 2011).

The presence of the COVID-19 outbreak has more or less disrupted student character-building activities. All levels of education, both formal and non-formal, are affected by the COVID-19 pandemic. Finally, all educational institutions are not allowed to carry out face-to-face teaching in schools. During this pandemic period, which began around the end of March 2020, the Ministry of Education and Culture implemented the rules for learning from home, hoping that schools would not become a new cluster for the spread of COVID-19. During the COVID-19 pandemic, there was inequality in the world of education. The trend of children's rights violations during the COVID-19 pandemic tended to increase compared to previous years. The Covid condition has an impact on cases experienced by children. During $2020 \mathrm{KPAI}$ received 6,519 (six thousand five hundred and nineteen) reports of cases of violations of children's rights.

\begin{tabular}{|c|c|c|c|c|c|c|c|}
\hline & \multirow{3}{*}{ Cluster } & amiss & on $2 C$ & $16-2$ & 20 & & \\
\hline \multirow[t]{2}{*}{ No } & & \multicolumn{5}{|c|}{ Years } & \multirow[t]{2}{*}{ Total } \\
\hline & & 2016 & 2017 & 2018 & 2019 & 2020 & \\
\hline 1 & $\begin{array}{l}\text { Social and children in } \\
\text { emergency situations }\end{array}$ & 236 & 286 & 302 & 291 & 128 & 1243 \\
\hline 2 & Family and alternative care & 857 & 714 & 857 & 896 & 1622 & 4946 \\
\hline 3 & Religion and culture & 262 & 240 & 246 & 193 & 139 & 1080 \\
\hline 4 & Civil rights and participation & 137 & 173 & 147 & 108 & 84 & 649 \\
\hline 5 & Health and Drugs & 383 & 325 & 364 & 344 & 70 & 1486 \\
\hline
\end{tabular}




\begin{tabular}{|c|c|c|c|c|c|c|c|}
\hline 6 & Education & 427 & 428 & 451 & 321 & 1567 & 3194 \\
\hline 7 & Pornography and cybercrime & 587 & 608 & 679 & 653 & 651 & 3178 \\
\hline 8 & Children in conflict with the law & 1314 & 1403 & 1434 & 1251 & 1098 & 6500 \\
\hline 9 & Trafficking and exploitation & 340 & 347 & 329 & 244 & 149 & 1409 \\
\hline 10 & Other child protection cases & 79 & 55 & 76 & 86 & 1011 & 1307 \\
\hline
\end{tabular}

The data illustrates that the pandemic condition has had an impact on student learning at school. The case in the family cluster and alternative care illustrates how the condition of conflicted parents has had a domino effect on children. In the case of education, learning from home causes complaints related to school policies to increase dramatically. The learning situation in the pandemic era continues to have challenges, and adaptation needs so that the fulfilment of children's education rights remains of high quality regardless of the circumstances and situations. Students lose access to normal face-to-face learning and education in class. As producers who create and develop learning scenarios, teachers must develop learning strategies by innovating through the synergy of information and technology. The teacher is a very influential person in the teaching and learning process. A teacher must bring his students to the goal to be achieved.

Several experts state the importance of character building in primary education. According to Freud, basic education is the key to character building so that students have good personalities. The success of teachers in guiding and overcoming various personality conflicts in primary education will determine the success of children in their lives in the future. The level of primary education has a significant role in character building. This, in addition to the initial foundation of primary education, is a stage where students imitate a lot of activities carried out by teachers and friends. If character cultivation cannot be carried out effectively, the student does not have an optimal personality. Therefore, if moral cultivation cannot be carried out properly at an elementary age, it will impact the morals of children in the future (Aslan \& Aybek, 2020; Saputro, 2020; Widodo et al., 2020; Wright et al., 2008). So that success in realizing character at that age will be a parameter to build students' personalities at the next level of education (Y Z Ansori, 2020).

The attitude of tolerance needs to be instilled by the teacher in the learning process in the classroom. Tolerance is interpreted as an attitude of respecting the differences that exist between one person and another. Elementary schools need to be given a good understanding of tolerance to understand and accept the differences between students. Pluralism is very clearly illustrated in the object of this research. Based on the results of observations and interviews with the principal of SDN I Kadipaten, the elementary school students come from different backgrounds, both ethnicity, religion, and race. From the ethnic aspect at the school, there are Minang, Javanese, and Sundanese; from the religious element, there are Islam, Christianity, and Buddhism, while from the racial aspect, there are indigenous and Chinese. Even though there are different cultures, respect in plural life is reflected in the association at school. Despite being surrounded by diverse cultures, they can maintain a pleasant attitude toward one another, both during interactions and daily activities. However, each religion is obligated to uphold faith and God's word according to their beliefs. People still guard their hearts and nurture their true character so that their hearts are not darkened by lust and animal instincts but are beautifully controlled by love, passion in truth, and the practice of all values. However, students lack tolerance for differences in ethnicity, religion, race, and between groups. Of course, suppose these differences are not maintained. In that case, they are very vulnerable to conflict due to differences in cultural and religious identities, according to the opinion that one's cultural and religious identity will be the primary source of competition in the post-cold war world. (Huntington, 2015). The distance from the school to the church is 30 meters, and all levels have two classes except for grade 1 there are three classes.

Success in growing the character of tolerance is strongly supported by learning strategies that synergize between technology and information. The development of m-learning character education based on multicultural values changes in learning styles that synergize current technological 
developments. M-learning is also seen as a solution. Preventing the spread of Covid-19, the activities do not have to be done face-to-face. They have been packaged in the content on each student's smartphone. The manufacture of m-learning is in line with the Ministry of Education and Culture's policy, particularly the Majalengka Regency Government, which has required all schools to implement Distance Learning (PJJ) through an online system to reduce new clusters of covid 19.

By developing m-learning character education based on multicultural values, students will be equipped with values that can erode the potential for conflict and discrimination. M-Learning is a learning process that can be carried out involving devices, in this case, mobile phones, laptops, and PCs (Buchori et al., 2016; Diacopoulos \& Crompton, 2020; Ismail et al., 2018). Accessors can see and access the learning process without being limited by time and space. On the other hand, M-Learning is a learning process that utilizes technology and information. M-Learning provides access to learning opportunities for students using attractive audio and visuals.

Certain hands-on materials are incompatible with M-Learning. Additionally, M-Learning is suitable for use as a classroom learning process. Among the intriguing aspects of M-Learning is the expanded range of connectivity. It is because the device used for access is easy to use anywhere and anytime so that users can more easily carry out learning in class (Abdjul et al., 2020; Lazar \& Moysey, 2020; Liu et al., 2016; Mishra, 2020; Poláková \& Klímová, 2020).

Others have widely studied the role of mobile learning in improving character education. Some research is done (Abdjul et al., 2020; Laranjeiro, 2021; Senduk et al., 2016; Wijayanti et al., 2019; Yeh et al., 2010) M-learning could be used as a means to improve student character education. One of the characteristics that can be accustomed and effective to exemplify through M-Learning is learning independence (Laranjeiro, 2021; Senduk et al., 2016). It is necessary to design E-Learning media that can develop student character in student learning in elementary schools.

\section{METHOD}

This research method is quasi-experimental. The design used in this study was a pre and postexperimental design. This design is used to see changes that occur before and after the treatment carried out by researchers. The difference that occurs after being given this treatment is the result of giving M-Learning conducted by the researcher. The instrument used is a tolerance questionnaire made by the researcher. The population and sample in this study were fourth-grade students of SDN Kadipaten 1 Majalengka Regency. The data collection technique used a test designed to see one character education: the attitude of tolerance in students. Data analysis using pre and post-test is to know the extent to which changes in students' character, namely the attitude of tolerance that occurs due to the use of M-Learning.

\section{FINDINGS AND DISCUSSION}

Mobile learning is a learning media used on mobile devices or smartphones. Learning media in the form of mobile learning is a media that presents various features such as animation and games (Alnabhan \& Aljaraideh, 2014; Ramud et al., 2018; Zakaria et al., 2019). Mobile learning media allows students to learn independently and under teacher guidance and can increase student motivation to learn. Mobile learning is an interactive learning media so that in the learning process, students not only listen to the teacher delivering the material but students are also active in learning. The presence of mobile learning in the learning process can increase student motivation to learn. If student motivation is good, a quality learning process will be created, significantly affecting learning outcomes. The display of mobile learning can be seen as follows: 


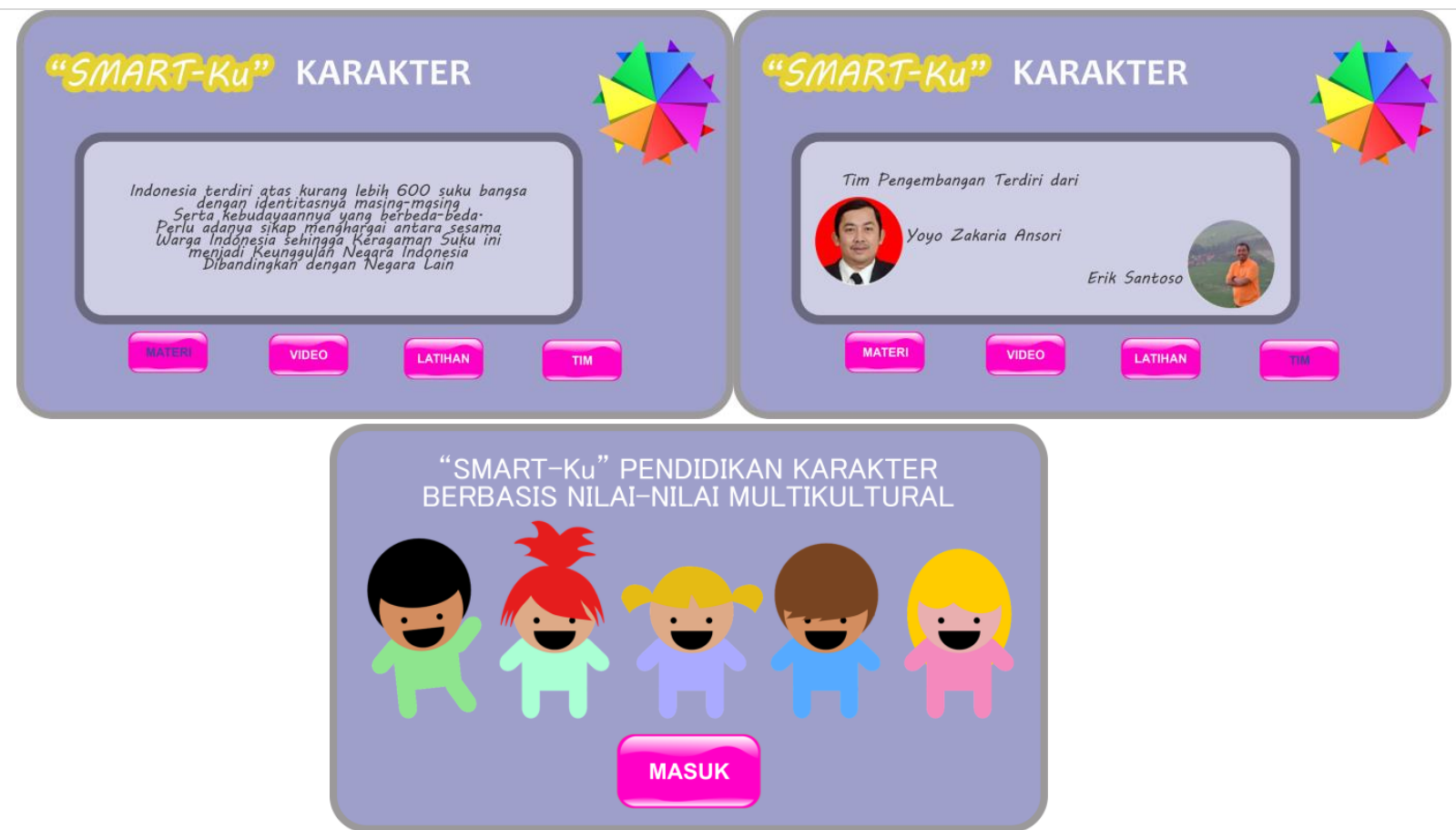

\section{Figure 1. Display of "My Smart” Mobile Learning Character Education Based on Multicultural Values}

Society needs to be equipped with values that can erode the potential for intolerance and discrimination. The development of mobile learning character education based on multicultural values is seen as a solution to answer these problems. The M-Learning display created is part of a reflection of tolerance which is an attitude of respecting differences. M-Learning "Smart-Ku" is designed with a simple interface to be well understood by students. M-Learning "Smart-Ku" consists of 4 main parts: materials, videos of tolerance and exercises, and the development team for the MLearning application "Smart-Ku." The material section contains materials related to the attitude of tolerance between fellow human beings accompanied by real examples that can be applied in everyday life. The material also presented problems that students often encounter in their daily lives, such as the following examples:

Dani is a new student at SDN Kadipaten 1 Majalengka. He is a student who comes from the Batak tribe and does not yet understand the Sundanese language that is often used every day at school. Dani is also a Catholic student. What is your attitude towards Dani? In this case, students are given a basic understanding of the meaning of good tolerance between one student and another. It is helpful so that students can understand tolerance and respect the differences between each other.

The researchers measured the attitude of tolerance both before and after they learned and understood it. The results of the attitude of tolerance are as follows:

Table 2. Attitudes of Tolerance of Students at SDN Kadipaten 1 Majalengka

\begin{tabular}{lcc}
\hline \hline $\begin{array}{l}\text { Category } \\
\text { Attitude } \\
\text { Tolerance }\end{array}$ & $\begin{array}{c}\text { Before M- } \\
\text { Learning } \\
\text { "Smart-Ku" }\end{array}$ & $\begin{array}{l}\text { Before } \\
\text { Learning } \\
\text { "Smart-Ku" }\end{array}$ \\
\hline High & $34 \%$ & $52 \%$ \\
Currently & $58 \%$ & $48 \%$ \\
Low & $8 \%$ & - \\
Total & $100 \%$ & $100 \%$ \\
\hline \hline
\end{tabular}

Based on these data, it is clear that there are differences in the attitude of tolerance after carrying out learning and providing an understanding through the "Smart-Ku" Before M-Learning application. This application is designed so that students can accept differences as an inseparable 
part of the diversity of Indonesian culture. After being analyzed based on the frequency distribution, then proceed with testing with the normality test first. The normality test results showed that the distribution of tolerance attitude data before and after using Before M-Learning "Smart-Ku" was normally distributed. Then the test is carried out with the paired-sample t-test to see the difference. The result of the paired-sample t-test is a significance value of $0.02<0.05$. Thus, it can be concluded that there are differences in tolerance attitudes before and after using M-Learning "Smart-Ku."

M-Learning "Smart-Ku" has several advantages, including a device that is easy to use and can be accessed anywhere and anytime by students. Then M-Learning "Smart-Ku" is also designed to understand tolerance for elementary school students. The examples given are real examples and are found in everyday life. As the example shown is as follows:

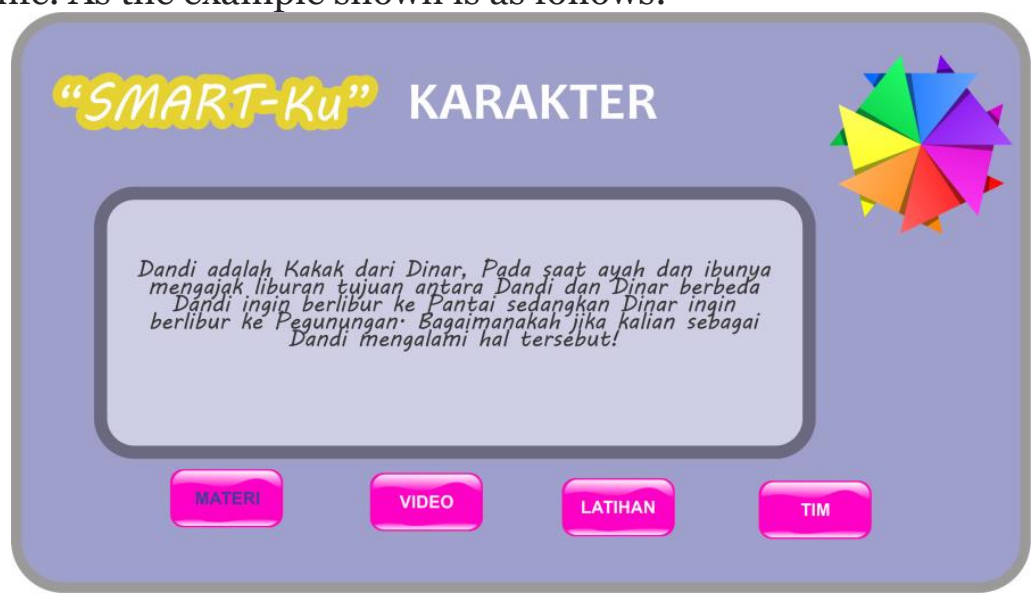

\section{Figure 2. Display of "My Smart" Mobile Learning Attitude Appreciating Differences that Occur in the Family Environment}

Character building in educational institutions is a mandate from the Preamble to the 1945 Constitution of the Republic of Indonesia, namely Pancasila, as the basis of the state and the view of the life of the Indonesian nation, which must animate all fields of development. One of the fields of national development that is very important and becomes the foundation of social, national, and state life is the development of the nation's character. This is in line with the National Policy for Development of National Character as implementing the National Long-Term Development Plan mandate for 2005-2025.

Schools as educational institutions have a big responsibility to realize this mandate. The expected national character is stated plainly in Law No. 20 of 2003 concerning the National Education System (Sisdiknas) chapter II article 3, which says that national education serves to develop capabilities and shape the character and civilization of a dignified nation within the context of educating the nation's life, to develop students' potential to become human beings who believe and act. Almighty, noble, healthy, knowledgeable, capable, creative, independent, and become a democratic and responsible citizen. At the practical level, the Ministry of National Education has identified 18 character values that must be realized in students. These characters are the central values embedded from religion, Pancasila, culture, and national education goals. Of the eighteen character values, one value is considered urgent and allows clashes between cultures, races, ethnicities, religions, and values that apply in society if not handled early on. The value in question is tolerance.

Tolerance is a part that students must give understanding. Educators, in this case, teachers must instil an attitude of tolerance from an early age. This is because tolerance is the most crucial part of appreciating the progress of a nation. Learning using M-Learning "Smart-Ku" can be used as a means by educators in providing a good understanding of how to appreciate differences with cases that elementary school students often encounter. (Gallego et al., 2020; Patricia Aguilera-Hermida, 2020; Voronchenko et al., 2015). According to the opinion, the "Smart-Ku" M-Learning application can provide a good understanding of this tolerance attitude (Lestari, 2019). Therefore, mobile learning-based applications can be developed to grow students' abilities and attitudes (Abdjul et al., 
2020; Alnabhan \& Aljaraideh, 2014; Hanif, 2020; Mishra, 2020; Ramud et al., 2018). Friendly applications need to be developed by educators to provide students with an understanding of the attitudes that characterize the Indonesian nation as an Eastern nation with good manners following the characteristics of the Indonesian state.

\section{CONCLUSION}

Based on the data processing and analysis results, it can be concluded that the attitude of tolerance needs to be given a good understanding at the level of elementary school students. This is because elementary school students are at a stage where imitation is very high. The "Smart-Ku" MLearning application can be a facility in providing an understanding of tolerance. It is shown that the results of the study show that there are differences in tolerance attitudes before and after using the "Smart-Ku" M-Learning application. The limitation of this study is that some students do not take part in learning using M-Learning due to a lack of information because the school has a home learning system. Then the character is assessed on tolerance, so it is necessary to develop other student characters that can be used as material for further research development.

\section{REFERENCES}

Abdjul, T., Uloli, R., \& Payu, C. (2020). The Influence of M-Learning Based Ryleac Learning Model Towards Students' Character In SMA 1. European Journal of Education Studies, 7(12), 193201. https://doi.org/10.46827/ejes.v7i12.3406

Alnabhan, M. M., \& Aljaraideh, Y. (2014). Collaborative M-learning adoption model: A case study for Jordan. International Journal of Emerging Technologies in Learning, 9(8), 4-10. https://doi.org/10.3991/ijet.v9i8.3639

Alwasilah, A. C. (2012). Pokoknya Rekayasa Literasi. Kiblat.

Ansori, Y Z. (2020). Menumbuhkan Nilai-Nilai Multikultural Dalam Pendidikan Agama Islam. Seminar Nasional Pendidikan: FKIP UNMA.

Ansori, Yoyo Zakaria, Budiman, I. A., \& Nahdi, D. S. (2019a). Islam Dan Pendidikan Multikultural. In Jurnal Cakrawala Pendas (Vol. 5, Issue 2). https://doi.org/10.31949/jcp.v5i2.1370

Ansori, Yoyo Zakaria, Budiman, I. A., \& Nahdi, D. S. (2019b). Pembinaan Nilai-Nilai Multikultural pada Masyarakat dalam Mengantisipasi Dampak Keberadaan Bandara Internasional Jawa Barat di Kecamatan Kertajati, Majalengka. Jurnal Pengabdian Pada Masyarakat, 4(3), 321328. https://doi.org/10.30653/o02.201943.167

Aslan, S., \& Aybek, B. (2020). Testing the Effectiveness of Interdisciplinary Curriculum-Based Multicultural Education on Tolerance and Critical Thinking Skill. International Journal of Educational Methodology, 6(1), 43-55. https://doi.org/10.12973/ijem.6.1.43

Buchori, A., Setyosari, P., Wayan Dasna, I., \& Ulfa, S. (2016). Developing character building learning model using mobile augmented reality on elementary school student in Central Java. Global Journal of Pure and Applied Mathematics, 12(4), 3433-3444.

Diacopoulos, M. M., \& Crompton, H. (2020). A systematic review of mobile learning in social studies. Computers \& Education, 154, 103911. https://doi.org/https://doi.org/10.1016/j.compedu.2020.103911

Gallego, A., McHugh, L., Villatte, M., \& Lappalainen, R. (2020). Examining the relationship between public speaking anxiety, distress tolerance and psychological flexibility. Journal of Contextual Behavioral Science, 16, 128-133. https://doi.org/https://doi.org/10.1016/j.jcbs.2020.04.003

Hanif, M. (2020). Students' Self-Regulated Learning in Iconic Mobile Learning System in English Cross-Disciplined Program. Anatolian Journal of Education, 5(2), 121-130. https://doi.org/10.29333/aje.2020.5210a

Huntington, S. P. (2015). The clash of civilizations? In Conflict After the Cold War: Arguments on Causes of War and Peace. American Enterprise Institute. https://doi.org/10.4324/9781003060963-50

Ismail, N. S., Harun, J., Zakaria, M. A. Z. M., \& Salleh, S. M. (2018). The effect of Mobile problembased learning application DicScience PBL on students' critical thinking. Thinking Skills and Creativity, 28, 177-195. https://doi.org/https://doi.org/10.1016/j.tsc.2018.04.002 
Itzchakov, G., \& Reis, H. (2020). Perceived Responsiveness Increases Tolerance of Attitude Ambivalence and Enhances Intentions to Behave in an Open-Minded Manner. Personality and Social Psychology Bulletin. https://doi.org/10.1177/0146167220929218

Laranjeiro, D. (2021). Development of game-based m-learning apps for preschoolers. Education Sciences, 11(5). https://doi.org/10.3390/educsci11050229

Lazar, K. B., \& Moysey, S. M. (2020). Enabling student self-guided field expeditions in geoscience with the GeoXploration platform for mobile apps. Applied Computing and Geosciences, 7 (May), 100028. https://doi.org/10.1016/j.acags.2020.100028

Lestari, W. (2019). Need Analysis in the Development of Hots-Oriented Study Project Assesment Instrument in Android-Based Science Learning. Journal of Research and Educational Research Evaluation, 8(1), 57-64. https://doi.org/10.15294/jere.v8i1.31799

Liu, Y., Holden, D., \& Zheng, D. (2016). Analyzing students' Language Learning Experience in an Augmented Reality Mobile Game: An Exploration of an Emergent Learning Environment. Procedia - Social and Behavioral Sciences, 228(June), 369-374. https://doi.org/10.1016/j.sbspro.2016.07.055

Ma `arif, M. A. (2019). Internalisasi Nilai Multikulutural Dalam Mengembangkan Sikap Toleransi ( Studi Di Di Pesantren Mahasiswa Universitas Islam Malang). Nazhruna: Jurnal Pendidikan Islam, 2(1). https://doi.org/10.31538/nzh.v2i1.179

Mishra, S. (2020). Learning from Usage Analysis of Mobile Devices. Procedia Computer Science, 167(2019), 1648-1655. https://doi.org/10.1016/j.procs.2020.03.375

Patricia Aguilera-Hermida, A. (2020). College students' use and acceptance of emergency online learning due to COVID-19. International Journal of Educational Research Open, 1(July), 100011. https://doi.org/10.1016/j.ijedro.2020.100011

Poláková, P., \& Klímová, B. (2020). Assessment of vocabulary knowledge through a mobile application. Procedia Computer Science, 176, 1523-1530. https://doi.org/10.1016/j.procs.2020.09.163

Ramud, N. A., muchtar, zainuddin, \& hutabarat, wesley. (2018). The Development Of Flash Program Based Mobile Learning (M-Learning) On Colloidal System Material. 200, 156-158. https://doi.org/10.2991/aisteel-18.2018.32

Roslinda, R. (2020). Identifikasi Karakter Toleransi Siswa Pada Mata Pelajaran IPA di-SMPN 17 Batanghari. Journal Evaluation in Education (JEE), 1(1), 08-14. https://doi.org/10.37251/jee.v1i1.16

Saputro, F. E. (2020). the Role of Islamic Religious Education Teachers in Actualizing Tolerance Attitudes To Students. AL-ISHLAH: Jurnal Pendidikan, 12(2), 336-347. https://doi.org/10.35445/alishlah.v12i2.214

Senduk, E. P., Sinsuw, A., \& Karouw, S. (2016). M-Learning Pendidikan Karakter untuk Anak Usia Dini Berbasis Augmented Reality. Jurnal Teknik Informatika, 9(1), 1-5. https://doi.org/10.35793/jti.9.1.2016.14929

Shaposhnikova, T. L., Marina Leonidovna Romanova, \& Tarasenko, N. A. (2013). Conditions to Inculcate Tolerance in Students Tatiana. Life Science Journal 2013, 1O(11), 325-330.

Standley, J. M. (2000). Increasing Prospective Music Educators' Tolerance for Student Diversity. Update: Applications of Research in Music Education, 19(1), 27-32. https://doi.org/10.1177/875512330001900106

Tilaar, H. A. R. (2004). Multikulturalisme : tantangan-tantangan global masa depan dalam transformasi pendidikan nasional. Gramedia Widiasarana Indonesia.

Vangrunderbeek, H., \& Tolleneer, J. (2011). Student attitudes towards doping in sport: Shifting from repression to tolerance? International Review for the Sociology of Sport, 46(3), 346357. https://doi.org/10.1177/1012690210380579

Verma, C., Illés, Z., \& Stoffová, V. (2020). Identifying technology features impacted attitude of Indian students using regression modeling for real-time system. Materials Today: Proceedings, 42, 297-303. https://doi.org/10.1016/j.matpr.2020.08.583

Voronchenko, T., Klimenko, T., \& Kostina, I. (2015). Learning to Live in a Global World: ProjectBased Learning in Multicultural Student Groups as a Pedagogy of Tolerance Strategy. Procedia - Social and Behavioral Sciences, 191, 1489-1495. https://doi.org/10.1016/j.sbspro.2015.04.472

Widodo, A., Maulyda, M. A., Fauzi, A., Sutisna, D., Nursaptini, N., \& Umar, U. (2020). Tolerance Education Among Religious Community Based on the Local Wisdom Values in Primary 
Schools. 465(Access 2019), 327-330. https://doi.org/10.2991/assehr.k.200827.082

Wijayanti, D. M., Ahmadi, F., \& Sarwi, S. (2019). Keefektifan Mobile Learning Media Bermuatan Ethnoscience terhadap Hasil Belajar Siswa Sekolah Dasar. MODELING: Jurnal Program Studi PGMI, 6(2), 129-136. https://doi.org/10.36835/modeling.v6i2.463

Wright, J. C., Cullum, J., \& Schwab, N. (2008). The cognitive and affective dimensions of moral conviction: Implications for attitudinal and behavioral measures of interpersonal tolerance. Personality and Social Psychology Bulletin, 34(11), 1461-1476. https://doi.org/10.1177/0146167208322557

Yeh, H. C., Yang, Y. F., \& Wong, W. K. (2010). Interaction chain patterns of online text construction with lexical cohesion. Educational Technology and Society, 13(1), 55-68.

Zakaria, M. I., Mistima Maat, S., \& Khalid, F. (2019). A Systematic Review of M-learning in Formal Education. International Journal of Innovation, Creativity and Change. Www.Ijicc.Net, 7(11). www.ijicc.net 